\title{
Single-Dose and Combined-Dose of Nanoparticles from Soursop Leaves (Annona muricata L.) and Sappan Wood (Caesalpinia sappan L.) Induced Apoptosis and Necrosis in HeLA Cells
}

\author{
Okid Parama Astirin' , Adi Prayitno ${ }^{2}$, Anif Nur Artanti ${ }^{3}$, Elisa Herawati ${ }^{1 *}$, Afiyati Nur 'Aini Saad ', Ajeng Dara Firstlia'
}

\author{
Okid Parama Astirin', Adi \\ Prayitno ${ }^{2}$, Anif Nur Artanti ${ }^{3}$, Elisa \\ Herawati ${ }^{1, *}$, Afiyati Nur 'Aini \\ Saad $^{1}$, Ajeng Dara Firstlia' ${ }^{1}$
}

'Department of Biology, Faculty of Mathematics and Natural Sciences, Sebelas Maret University, Surakarta, INDONESIA.

Dy, Faculy of Medicine,

2Department of Pathobiology, Faculty of Medicine Sebelas Maret University, Surakarta, INDONESIA. ${ }^{3}$ Department of Pharmacy, Vocational College, Sebelas Maret University, Surakarta, INDONESIA.

\section{Correspondence}

\section{Elisa Herawati}

Department of Biology, Faculty of Mathematics and Natural Sciences, Sebelas Maret University, Surakarta INDONESIA

E-mail: elisahera@staff.uns.ac.id

History

- Submission Date: 14-06-2021;

- Review completed: 11-07-2021;

- Accepted Date: 14-07-2021.

DOI : 10.5530/pj.2021.13.146

Article Available online

http://www.phcogj.com/v13/i5

Copyright

(C) 2021 Phcogj.Com. This is an openaccess article distributed under the terms of the Creative Commons Attribution 4.0 International license.

\begin{abstract}
Introduction: Apart from the medical advancement of chemotherapy, various plants were known as beneficial for cancer therapy because they can kill cancer cells selectively without damaging the normal cells. Here, we showed that nanoparticles formulated from chloroform fraction of soursop (Annona muricata L.) leaves and ethyl acetate fraction of sappan wood (Caesalpinia sappan L.) have anti-proliferative and cytotoxic effects on HeLa cervical cancer cells. Methods: The cytotoxic effect was evaluated using a single dose of each nanoparticle and a combined dose to obtain a synergistic effect. The mechanism of induced cell death via apoptosis or necrosis pathway was evaluated using flow cytometry by incorporating Annexin $V$ and propidium iodide. Results: Synthesis of nanoparticles from the extract of soursop leaves (nano-SL) and extract of sappan wood (nano-SW) yielded particle sizes ranging from 248 to $317 \mathrm{~nm}$. Nano-SL and nano-SW decreased the viability of HeLa cervical cancer cells in a dose-dependent manner with $\mathrm{IC}_{50}$ values of $63,32 \mu \mathrm{g} / \mathrm{ml}$ dan $40,88 \mu \mathrm{g} / \mathrm{ml}$, respectively. The combined dose of $1 / 8 \mathrm{IC}_{50}$ from both nanoparticles showed a strong synergistic effect, as shown by the combination index value of 0.13 based on the same mode of action and different modes of action. In HeLa cells treated with a combined dose of nanoparticles, the total apoptotic cells increased two times greater than that in control cells. Conclusion: Nano-SL and nano-SW induce apoptosis and necrosis in HeLa cells. Combined-dose of both nanoparticles produced a synergistic effect that could reduce the amount of the required individual dose while increasing the total effect.

Key words: Annona muricata L., Apoptosis, Caesalpinia sappan L., HeLa cells, Nanoparticles, Necrosis.
\end{abstract}

\section{INTRODUCTION}

Cervical cancer is the second most common type of malignant tumor in women. ${ }^{1}$ The incidence of cervical cancer is quite high among ASEAN countries. In Indonesia, the number of cervical cancer patients reached $36 \%$, thus, without appropriate health measures and treatments, the number of cervical cancer deaths is projected to increase by almost $25 \%$ over the next decade. ${ }^{2}$ The common cancer treatment chemotherapy often poses side effects, including non-selective activity against targeted tissue which destroying normal cells around the cancer site. ${ }^{3}$ Because of this, the discovery of new compounds and/or combination treatment that selectively kill cancer cells without affecting normal cells is necessary. ${ }^{4}$

Sappan wood (Caesalpinia sappan L.), has been known for its cytotoxic, anti-cancer, antitumor, anti-microbial, immunostimulant, immunosuppressive, anti-inflammatory, and antioxidant activity. The extract of sappan wood induced cervical cancer cell death, associated with increased $\mathrm{p} 53$ and $\mathrm{p} 21 \mathrm{WAF} 1$ / CIP1 protein expression at the cellular level. ${ }^{5}$ It also induces apoptosis in several other types of cancer cells, such as promyelocytic leukemia cells HL- $60^{6}$ and leukemia K562 cells. ${ }^{7}$ The pharmacological activities from sappan wood were attributed to its several compounds, e.g., brazilin $\left(\mathrm{C}_{16} \mathrm{H}_{14} \mathrm{O}_{5}\right)$, sappanin $\left(\mathrm{C}_{12} \mathrm{H}_{12} \mathrm{O}_{4}\right)$, brazilein, and essential oils such as $\mathrm{D}$ - $\alpha$-felandrena, gallic acid, osinema, and resin. Brazilin and brazilein are found in the wood part and showed anti-inflammatory activity. ${ }^{8}$ Furthermore, the antioxidant power of the aqueous extract of sappan wood was higher than commercial antioxidants (BHT and BHA), suggesting its potential source of free radical scavenger. ${ }^{9}$

Soursop leaves (Annona muricata L.) are a natural ingredient commonly used to treat various diseases, including cancer. ${ }^{10}$ Annonaceous acetogenins compounds are only found in the Annonaceae family, which is a large group of phytochemical that naturally serve as an anticancer agent. This compound is not only effective in killing cancer cells but also showed a higher affinity for some resistant cells. ${ }^{11}$ Several mechanisms of acetogenin-induced toxicity against cancer cells have been widely studied, including the inhibition of complex I mitochondrial electron transport which caused ATP depletion to promote cancer cell death. ${ }^{12,13}$ Acetogenin, especially the annonacin type, attenuates the cancer cell cycle in the G1 phase and inhibits the progression to the $\mathrm{S}$ phase by upregulating the expression of $\mathrm{p} 53, \mathrm{p} 21$, Bax, and Bad in the prostate cancer cell line. ${ }^{14}$ Our previous study showed the polyketide isolated from soursop leaves inhibited the growth of nasopharyngeal cancer cell lines and displayed a cytotoxic effect in Raji cells with $\mathrm{IC}_{50}$ value of $71.96 \mu \mathrm{g} / \mathrm{ml}$. Necrosis or apoptosis might cause decreased cell viability in these cells, thus, polyketide from soursop leaves has the potential to be developed as co-chemotherapy agents in Raji cells via the $\mathrm{p} 53$ pathway. ${ }^{15}$ 
Nanotechnology-based anticancer agents have been able to selectively targeted and intracellularly taken up by cervical cancer HeLa cells. Anticancer agents can serve as a matrix or attach to nanoparticles. ${ }^{16}$ Studies on the application of nanoparticles have attracted increasing interest from researchers because the development of materials at the nanoscale could improve the physical, mechanical, and chemical properties of a material without destroying its atomic structure. ${ }^{17}$ The nanoparticle drug delivery system often incorporated chitosan, a natural biopolymer that serves as a carrier. Chitosan has reactive amino groups and hydroxyl functional groups and the ability to increase membrane permeability. It is one of the most promising immobilization matrices because it can form membranes, displays good adhesion properties, affordable price, non-toxic, high mechanical strength and hydrophilicity, and improved stability. ${ }^{18}$

There are still limited studies confirming the anticancer activity of nanoparticles that are formulated using the extract of soursop leaves and sappan wood. In a study, ${ }^{19}$ the preparation of chitosan nanoparticles containing soursop leaves extracts yielded a particle size of $535.1 \mathrm{~nm}$ which showed potent cytotoxicity $\left(\mathrm{IC}_{50} 292.39 \mu \mathrm{g} / \mathrm{mL}\right.$ ) against human colon cancer. Meanwhile, most studies using sappan wood-derived nanoparticles were only focused on its antibacterial potency against many pathogenic bacteria. ${ }^{20}$ Here, we examined the anticancer effect of the combined soursop leaf nanoparticles (nanoSL) and sappan wood nanoparticles (nano-SW) against cervical HeLa cell lines. This study aimed at determining the optimum combination dose of both nano-SL and nano-SW that showed a synergistic effect to induce apoptosis and necrosis in HeLa cells. Using flow cytometry analysis, the result showed a 2.5 -fold increase of cell death by $1 / 8 \mathrm{IC}_{50}$ of combined doses as compared to single-dose administration of each nanoparticle, suggesting a plausible candidate for cancer treatment via co-chemotherapy agents.

\section{MATERIALS AND METHODS}

\section{Fractionation of Soursop Leaves (A. muricata L.) and Sappan Wood (C. sappan L.)}

Fractionation to obtain the active fraction was started by separating the active ingredient through extraction using the column chromatography method. Perfect separation was obtained using the stationary phase and the mobile phase. The factors that became the basis for selecting the two phases were the polarity and solubility of the soursop leaf extract and sappan wood extract. ${ }^{21}$

The fractionation of soursop (A. muricata) leaves was done using chloroform since the previous study ${ }^{22}$ has proven it as the most effective solvent to isolate the fraction with the best cytotoxic activity with an IC50 value of $166.32 \mu \mathrm{g} / \mathrm{mL}$. The samples of powdered-sappan wood (C. sappan) were obtained from Tawangmangu B2P2TO2T (Research and Development Center for Medicinal Plants and Traditional Medicines of the Health Research and Development Agency), Central Java, Indonesia. The extraction of sappan wood using ethanol was based on the method by Kim (2005). ${ }^{5}$ The ethanol extract of sappan wood was fractionated using the column chromatography method according to the Rubiyanto method (2017). ${ }^{23}$

\section{Synthesis of Nanoparticles}

The nanoparticle formulation of soursop leaf fraction and sappan wood fraction was carried out using the glass ionic method between chitosan and NaTPP (sodium tripolyphosphate) using an ultrasonicator. ${ }^{24}$ Soursop leaf fraction (12.5 mg) was dissolved in $125 \mu$ l Dimethyl Sulfoxide (DMSO). Sappan wood fraction $(12.5 \mathrm{mg})$ was diluted with $200 \mu$ of distilled water. A $0.2 \%$ chitosan solution was added to each solution fraction and homogenized with a vortex. The $0.1 \%$ NaTPP solution was dripped into the chitosan mixture and the fraction continuously at a stirring speed of $400 \mathrm{rpm}\left(25^{\circ} \mathrm{C}\right)$ until all the NaTPP solution runs out and a nanoparticle suspension was formed. ${ }^{24}$ Optimization of nanoparticle composition was done using Design Expert software. ${ }^{25}$ Based on the software design expert analysis in preliminary research, the optimum formula for creating nanoparticles of the soursop fraction was by dissolving it with DMSO and the sappan wood fraction was by dissolving it with distilled water.

\section{Determination of Particle Size, Measurement of Transmittance and Zeta Potential}

Determination of the particle size of the soursop leaf nanoparticle (nano-SL), sappan wood nanoparticle (nano-SW), and zeta potential was carried out by dispersing the particles with distilled water $(1: 1 \mathrm{v} / \mathrm{v})$ at $25^{\circ} \mathrm{C}$. Particle size was measured using Nanopartica SZ-100 (Horiba). The particle size distribution was expressed as the Polydispersion Index (PI) of the DLS analyzer where PI $<1$ represents good polydispersion. ${ }^{26}$ Transmittance was measured by a UV-Vis spectrophotometer with a wavelength of $650 \mathrm{~nm}$, as well as testing for particle size and zeta potential using a PSA (dynamic light scattering method).

\section{MTT Assay}

Experiments using HeLa cell cultures have obtained the ethical clearance from the Faculty of Medicine, Muhammadiyah University of Surakarta (No: 2307 / C.1 / KEPK-FKUMS / VII / 2019). HeLa cells were routinely cultured using RPMI 1640 medium with $20 \%$ FBS in an incubator with $5 \% \mathrm{CO} 2$ and $37^{\circ} \mathrm{C} . .^{27,28}$

HeLa cells were obtained from the LPPT, Gadjah Mada University. The cytotoxicity test method was done using the colorimetric cell viability with (3-[4,5-dimethylthiazol-2-yl] - 2,5 diphenyl tetrazolium bromide) or known as the MTT assay. ${ }^{29}$ The nano-SL and nano-SW were diluted using RPMI medium at various concentrations, i.e., 100, 50, 25, 12.5 , $6.25 \mathrm{ppm}$ for nano-SL; and 25, 12, 5, 6.25, 3.125, $1.5625 \mathrm{ppm}$ for nanoSW. A total of $1 \mathrm{ml}$ of MTT (0.5 mg / ml PBS) was diluted in RPMI (Gibco) culture medium, with the addition of 10\% Fetal Bovine Serum (FBS Qualified, Gibco, Invitrogen USA), 1.5\% (w / w) penicillinstreptomycin (Gibco, Invitrogen USA), and $0.5 \%$ fungizone (Gibco, Invitrogen USA). HeLa cells were incubated at $37^{\circ} \mathrm{C}$ and $5 \% \mathrm{CO} 2$. The absorbance read with an ELISA reader was analyzed calorimetrically using a wavelength of $595 \mathrm{~nm} .{ }^{30}$

\section{Flow Cytometry}

The flow cytometry method was used on the most active nanoparticle fractions that had cytotoxic potential against cervical cancer cell lines (HeLa cells). EDTA $0.25 \%$ trypsin (Gibco, Invitrogen) was used to separate the cell line and washed with the phosphate-buffered saline PBS (Sigma Aldrich). Addition of Annexin V-propidium iodine (BD Pharmigen ${ }^{\mathrm{m}}$ ), for a marker of cell death because of apoptosis or necrosis. The cell cycle profile was measured by flow cytometry (FACS, Calibur). ${ }^{31}$ Results from the flow cytometry were analyzed using the CellQuest software to visualize the distribution of cells in the phases of apoptosis and necrosis by comparing the effects of the test solution treatment with the control. ${ }^{32}$ The maximum absorbance of green light falls between $488-525 \mathrm{~nm}$, indicating living cells. In early apoptosis, cells emitted yellow fluorescence with a weak intensity at a wavelength of 536-617 nm. Cells that experience final necrosis or apoptosis will emit red fluoresce light at a wavelength of $650-700 \mathrm{~nm}^{33}$

\section{Combination Indices}

The combination index (CI) between the nano-SL and nano-SW was calculated using the equation: 
Astirin OP, et al.: Single-Dose and Combined-Dose of Nanoparticles from Soursop Leaves (Annona muricata L.) and Sappan Wood (Caesalpinia sappan L.) Induced Apoptosis and Necrosis in HeLA Cells

"same mode of action "

"different modes of action "

$\mathrm{IK}=\frac{(D) 1}{(D x) 1}+\frac{(D) 2}{(D x) 2}$ and $\mathrm{IK}=\frac{(D) 1}{(D x) 1}+\frac{(D) 2}{(D x) 2}+\frac{(D) 1(D) 2}{(D x) 1(D x) 2}$ where:

(D) 1 : concentration of soursop leaf fraction combination treatment (Dx) 1 : single treatment concentration of soursop fraction with D1 response

(D)2 : concentration of sappan wood fraction combination treatment

(Dx)2 : single treatment concentration of the sappan wood fraction with the D2 response

CI values were obtained using the Microsoft Excel (linear regression of the combined log test concentration) (CCRC, 2010). ${ }^{34}$ The CI value obtained was interpreted based on Reynolds \& Maurer (2005; Table 1). ${ }^{35}$

\section{RESULTS AND DISCUSSION}

Characterization of Nanoparticles from Chloroform Fractions of Soursop Leaf Extract and Ethyl Acetate Fractions of Sappan Wood Extract

The effective doses of soursop leaf extract and sappan wood in vivo were $100 \mathrm{mg} / \mathrm{kg} \mathrm{BW}{ }^{36}$ and $25 \mathrm{mg} / \mathrm{kg} \mathrm{BW},{ }^{37}$ respectively. To prepare nanoparticles from sappan wood chloroform fraction, we used half of the in vivo effective dosage $(12.5 \mathrm{mg})$. However, the corresponding half-dose of soursop leaf fraction was difficult to dissolve at higher concentration, therefore, we used $12.5 \mathrm{mg}$ of the fraction for nanoparticle formulation. Based on the analysis of Design-Expert software, ${ }^{25}$ the optimum formula for creating nanoparticles from the chloroform fraction of soursop leaf (nano-SL) is as follows:

$\mathrm{F}_{\text {opt }}=85.710 \%$ Chitosan $+14.290 \% \mathrm{NaTPP}$ (desirability value 0.639 )

Whereas the optimum formula for creating nanoparticles from the ethyl acetate fraction of sappan wood (nano-SW) is as follows:

$\mathrm{F}_{\text {opt }}=90.606 \%$ Chitosan $+9.394 \% \mathrm{NaTPP}$ (desirability value 0.910 )

The desirability value ranges from 0 to 1 . The greater the desirability value corresponds with a better total response. With a desirability value of 0.910 , nano-SW is likely to be very stable, thus, affecting the uniformity of the particle size distribution:

The particle size of nano-SL and nano-SW has met the range of nanoparticle size, i.e., $248.7 \mathrm{~nm}$ and $317.6 \mathrm{~nm}$, respectively (Table 2). Particle size is the most important characteristic in a nanoparticle system because it can determine the in vivo distribution, toxicity, and drug release. Accordingly, due to its small size, the suspension of nano-SL and nano-SW has a low level of turbidity and permitted light transmittance $94.231 \%$ (Table 2). Surface charge properties of the nanoparticles indicated by zeta potential was measured to determine the stability of a colloid system. In general, nanoparticles with a zeta potential value $(+/-)$ of $30 \mathrm{Mv}$ are regarded as stable suspension. ${ }^{38}$ However, the nano-SL may not yet develop into a stable colloid system because the value of its zeta potential fell above $30 \mathrm{mV}$. Likewise, the stability of the nano-SW colloid system is also still a major concern because the zeta potential value reached $1.26 \mathrm{mV}$, far below the $30 \mathrm{mV}$.

\section{Cytotoxic Effect of Single Doses of Nano-SL and Nano-} SW against HeLa cells

The cytotoxic effect of a single dose of each nano-SL and nano-SW in inhibiting the growth of HeLa cells is shown in Table 3. The results of the MTT assay showed that cell viability decreased as the concentration of nanoparticle samples increased. Treatment of a single nano-SL dose at $50 \mu \mathrm{g} / \mathrm{ml}$ reduced the viability of HeLa cells by $64.4 \%$. Meanwhile, a lower dose of nano-SW $(25 \mu \mathrm{g} / \mathrm{ml})$ exhibited a comparable toxicity effect, reducing HeLa cell viability by $65.49 \%$ (Table 3 ).

\section{Table 1: List of Combination Index $(\mathrm{CI})$ values and its interpretation. ${ }^{35}$}

\begin{tabular}{ll}
\hline Cl value & Interpretation \\
\hline$<\mathbf{0 . 1}$ & Extraordinarily strong synergistic action \\
$\mathbf{0 . 1 - 0 . 3}$ & Strong synergistic action \\
$\mathbf{0 . 3 - 0 . 7}$ & Synergistic action \\
$\mathbf{0 . 7 - 0 . 9}$ & Mild-moderate synergistic action \\
$\mathbf{0 . 9 - 1 . 1}$ & Approaching additive effect \\
$\mathbf{1 . 1 - 1 . 4 5}$ & Mild-moderate antagonistic effect \\
$\mathbf{1 . 4 5 - 3 . 3}$ & Antagonistic effect \\
$>\mathbf{3 . 3}$ & Strong-very strong antagonistic effect -
\end{tabular}

Table 2: Characteristics of nanoparticles from fraction of soursop leaf and fraction of sappan wood.

\begin{tabular}{llll|}
\hline Nanoparticles & Particle size $(\mathrm{nm})$ & $\begin{array}{l}\text { Transmittance } \\
(\%)\end{array}$ & $\begin{array}{l}\text { Zeta potential } \\
(\mathrm{mV})\end{array}$ \\
\hline Nano-SL & 248.7 & $80.139 \%$ & 46.6 \\
Nano-SW & 317.6 & $94.231 \%$ & 1.3
\end{tabular}

Table 3: Cytotoxic Effect of Single Dose of Nano-SL and Nano-SW.

\begin{tabular}{llll}
\hline $\begin{array}{l}\text { Nano-SL } \\
\begin{array}{l}\text { Concentration } \\
(\mu \mathrm{g} / \mathrm{ml})\end{array}\end{array}$ & Cell viability $(\%) \begin{array}{l}\text { Nano-SW } \\
\text { Concentration } \\
(\mu \mathrm{g} / \mathrm{ml})\end{array}$ & Cell viability $(\%)$ \\
\hline 6.25 & 76.48 & 1.5625 & 85.86 \\
12.5 & 76.96 & 3.125 & 83.6 \\
25 & 83.12 & 6.25 & 78.97 \\
50 & 64.4 & 12.5 & 71.12 \\
100 & 28.58 & 25 & 65.49
\end{tabular}

The relationship between cell viability and nanoparticle concentration was analyzed by linear regression to determine the $\mathrm{IC}_{50}$ value of the nanoparticle samples against HeLa cells (Figure 1). The regression coefficient shows a negative value, indicating a negative relationship between the nanoparticle concentration and the viability of HeLa cells. This means that an increase in the concentration of the fraction of nanoparticles corresponds with a decrease in the HeLa cells viability. Single doses of nano-SL and nano-SW inhibited the growth of HeLa cells with $\mathrm{IC}_{50}$ value of $63.32 \mu \mathrm{g} / \mathrm{ml}$ and $40.88 \mu \mathrm{g} / \mathrm{ml}$, respectively (Figure 1A-B). The $\mathrm{IC}_{50}$ value for cisplatin, a chemotheraphy drug used as positive control was $56.93 \mu \mathrm{g} / \mathrm{ml}$ (Figure 1C). The above results demonstrated that the cytotoxicity effect of nano-SW was greater than that of nano-SL and cisplatin. Notably, compounds with $\mathrm{IC}_{50}$ values $<100 \mu \mathrm{g} / \mathrm{ml}$ can be classified as a potent anti-proliferative compound, ${ }^{39}$ hence, both nano-SL and nano-SW are good candidates for attenuating cancer cell proliferation.

\section{Synergistic Effect of Combined Doses of Nano-SL and Nano-SW against HeLa Cells}

Because single doses of either nano-SL or nano-SW potentially deteriorate HeLa cell's viability, we hypothesize that a combination of nano-SL and nano-SW doses could elicit a more dramatic result. We examined whether the combination of the two could exhibit a synergistic, antagonistic, or additive cytotoxic effect. When the synergistic effect is favorable, the concentration of active compounds used in cancer therapy can be reduced.

The calculated combination indices (CIs) and their interpretations are presented in Table 4 and Table 5 . The same mode of action is reserved for drug combinations that are competitive inhibitors of each other, in other words, they both inhibit the same active site. Meanwhile, different modes of action are reserved for drug combinations that are non-competitive inhibitors of each other. ${ }^{35}$ 
Table 4: Combination indices based on same mode of action from nano-SL and nano-SW against HeLa cells.

\begin{tabular}{|c|c|c|c|}
\hline \multirow{2}{*}{ Nano-SW } & \multicolumn{3}{|l|}{ Nano-SL } \\
\hline & $1 / 8 \mathrm{IC}_{50}(7.195 \mu \mathrm{g} / \mathrm{ml})$ & $1 / 4 \mathrm{IC}_{50}(15.83 \mu \mathrm{g} / \mathrm{ml})$ & $1 / 2 \mathrm{IC}_{50}(31.66 \mu \mathrm{g} / \mathrm{ml})$ \\
\hline \multirow{2}{*}{$1 / 8 \mathrm{IC}_{50}(5.11 \mu \mathrm{g} / \mathrm{ml})$} & 0.13 & 0.21 & 0.29 \\
\hline & Strong synergistic action & Strong synergistic action & Strong synergistic action \\
\hline $1 / 4 \mathrm{IC}_{50}(10.22 \mu \mathrm{g} / \mathrm{ml})$ & $\begin{array}{l}0.33 \\
\text { Synergistic action }\end{array}$ & - & - \\
\hline $1 / 2 \mathrm{IC}_{50}(20.44 \mu \mathrm{g} / \mathrm{ml})$ & $\begin{array}{l}0.49 \\
\text { Synergistic action }\end{array}$ & - & - \\
\hline
\end{tabular}

Table 5: Combination indices based on different modes of action from nano-SL and nano-SW against HeLa cells.

\begin{tabular}{|c|c|c|c|}
\hline \multirow{2}{*}{ Nano-SW } & \multicolumn{3}{|l|}{ Nano-SL } \\
\hline & $1 / 8 \mathrm{IC}_{50}(7.195 \mu \mathrm{g} / \mathrm{ml})$ & $1 / 4 \mathrm{IC}_{50}(15.83 \mu \mathrm{g} / \mathrm{ml})$ & $1 / 2 \mathrm{IC}_{50}(31.66 \mu \mathrm{g} / \mathrm{ml})$ \\
\hline $1 / 8 \mathrm{IC}_{50}(5.11 \mu \mathrm{g} / \mathrm{ml})$ & $\begin{array}{l}0.13 \\
\text { Strong synergistic action }\end{array}$ & $\begin{array}{l}0.22 \\
\text { Strong synergistic action }\end{array}$ & $\begin{array}{l}0.31 \\
\text { Synergistic action }\end{array}$ \\
\hline $1 / 4 \mathrm{IC}_{50}(10.22 \mu \mathrm{g} / \mathrm{ml})$ & $\begin{array}{l}0.36 \\
\text { Synergistic action }\end{array}$ & - & - \\
\hline $1 / 2 \mathrm{IC}_{50}(20.44 \mu \mathrm{g} / \mathrm{ml})$ & $\begin{array}{l}0.53 \\
\text { Synergistic action }\end{array}$ & - & - \\
\hline
\end{tabular}

Table 6: Percent distribution of living cells, cells undergoing early and late apoptosis, and cells experiencing necrosis of different treatments analyzed using CellQuest program.

\begin{tabular}{|c|c|c|c|c|c|}
\hline & $\begin{array}{l}\text { Living cells } \\
(\%)\end{array}$ & $\begin{array}{c}\text { Early apoptotic } \\
(\%)\end{array}$ & Late apoptotic (\%) & $\begin{array}{c}\text { Total } \\
\text { apoptotic } \\
(\%)\end{array}$ & $\begin{array}{c}\text { Necrosis } \\
(\%)\end{array}$ \\
\hline Control & 83.36 & 7.61 & 2.43 & 10.04 & 6.6 \\
\hline Nano-SL only & 20.87 & 12.9 & 23.64 & 36.54 & 42.59 \\
\hline Nano-SW only & 67.83 & 9.09 & 4.93 & 14.02 & 18.14 \\
\hline $1 / 2 \mathrm{IC}_{50}$ of Combined doses & 58.27 & 22.07 & 11.2 & 31.9 & 8.46 \\
\hline
\end{tabular}
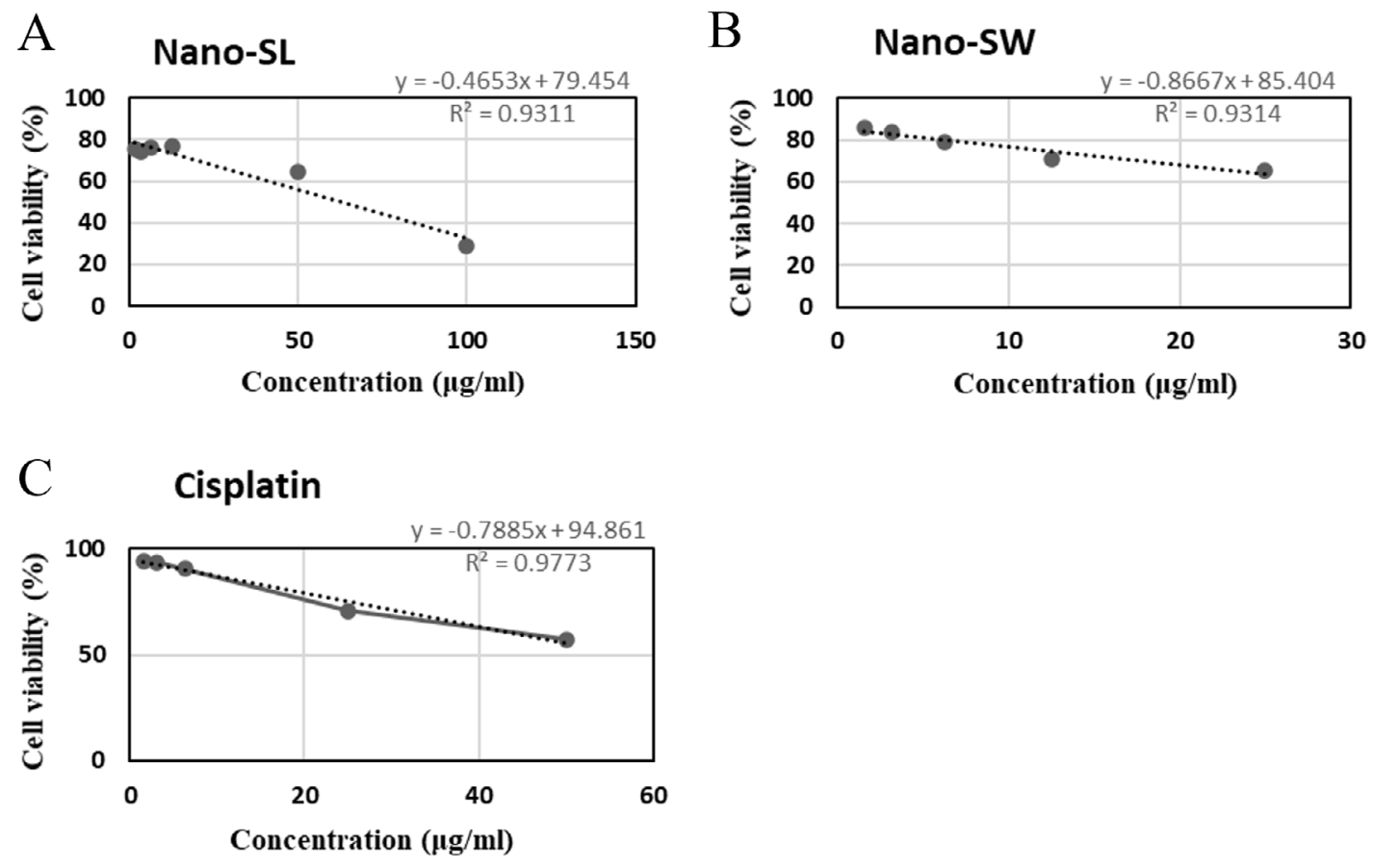

Figure 1: Graph of linear regression between HeLa cell's viability and concentration of the indicated samples; A) soursop leaf nanoparticles (nano-SL), B) sappan wood nanoparticles (nano-SW), C) Cisplatin. 
HeLa cells were assayed by MTT through various concentrations of nanoparticles from $1 / 8 \mathrm{IC}_{50}$ to $1 / 2 \mathrm{IC}_{50}$. Based on the same mode of action and different modes of action (Table 4-5), a strong synergistic effect was shown in the combination treatment of $1 / 8 \mathrm{IC}_{50}$ nano-SL with $1 / 8 \mathrm{IC}_{50}$ nano-SW. Under this condition, the viability of HeLa cells reduced by $18.2 \%$ (Figure 2 ). Compared with a single dose ( $\left.\mathrm{IC}_{50}\right)$ of each nanoparticle, the combined doses at $1 / 8 \mathrm{IC}_{50}$ produced a toxic effect about 2.7 times greater (Table 3 and Figure 2). The strong synergistic effect also applies to the combination of $1 / 4 \mathrm{IC}_{50}$ nano-SL with $1 / 8 \mathrm{IC}_{50}$ nano-SW, with the HeLa cell survival $20 \%$ higher than the combination of $1 / 8 \mathrm{IC}_{50}$ of the two nanoparticles (Figure 2).

\section{Analysis of Apoptosis and Necrosis by Flowcytometry}

The cytotoxic effect of the single-dose and combined dose of the two nanoparticles was further confirmed by flow cytometry using Annexin $\mathrm{V}$. Annexin V is a member of the phospholipid-binding protein family which strongly negatively charges cell membranes. Cell death caused by apoptosis or necrosis can be differentiated using Propidium Iodide (PI) staining by intercalation with DNA..$^{40}$ The flow cytometry method can distinguish living cells, early apoptosis, late apoptosis, and necrosis because Annexin V and PI reagents work selectively to bind intact and fragmented cells. Flow cytometry results were analyzed using the CellQuest program showing the distribution of living cells, cells undergoing early and late apoptosis, and cells experiencing necrosis (Table 6 and Figure 3).

Control cells were $83.3 \%$ viable, and some group of these cells that experienced apoptosis accounts for 10.04\% (Table 6 and Figure 3A). The total apoptotic cells increased after administration of single dose $\left(\mathrm{IC}_{50}\right)$ of nano-SL (36.54\%) or nano-SW (14.02\%) (Figure 3B-C). The remarkable number of necrotic cells $(42.59 \%)$ was also shown by single-dose nano-SL treated HeLa cells. Regarding nano-SW treatment, this result was somehow inconsistent with the MTT assay (Table 3) which suggested that at $\mathrm{IC}_{50}$ dose, nano-SL were less potent against HeLa cells as compared to nano-SW. The discrepancy might be attributed to the different sensitivity of MTT assay and flow cytometry, and the unstable nanoparticles in the colloid system as indicated by decreased zeta potential values (Table 2). When two nanoparticles were combined, the number of dead cells (apoptotic and necrotic) was higher than that of control cells (Table 6 and Figure 3D), albeit still below the dead cells affected by single-dose administration of nanoSL. Likewise, this phenomenon could be attributed to the fact that the resulting nanoparticles were unstable.

Cell death is a result of, among others, two distinct processes: apoptosis and necrosis. Apoptosis or programmed cell death is a normal process that has two functions, i.e., tissue repair and the release of damaged

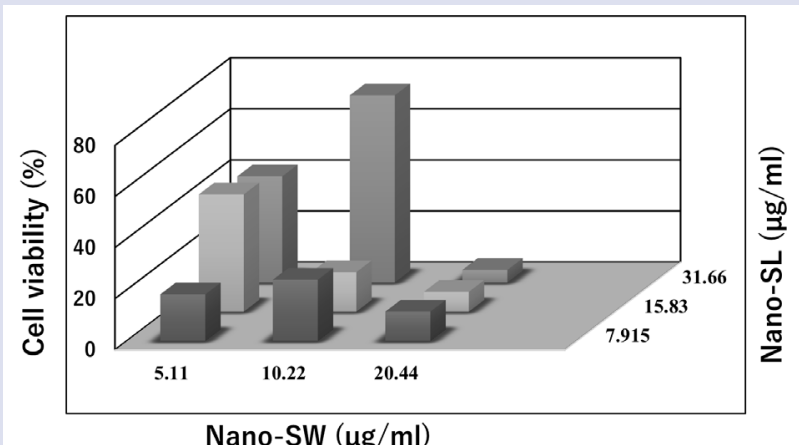

Figure 2: Cytotoxic effect of the combined doses of nano-SL and nanoSW against HeLa cell's viability. Doses of nano-SL includes $31.66 \mu \mathrm{g} / \mathrm{ml}$ $\left(1 / 2\right.$ IC $\left.C_{50}\right), 15.83 \mu \mathrm{g} / \mathrm{ml}\left(1 / 4 \mathrm{IC}{ }_{50}\right)$, dan $7.915 \mu \mathrm{g} / \mathrm{ml}\left(1 / 8 \mathrm{IC} \mathrm{C}_{50}\right)$. Doses of nano-SW includes $20.44 \mu \mathrm{g} / \mathrm{ml}\left(1 / 2 \mathrm{IC}_{50}\right), 10.22 \mu \mathrm{g} / \mathrm{ml}\left(1 / 4 \mathrm{IC} C_{50}\right)$, dan $5.11 \mu \mathrm{g} / \mathrm{ml}\left(1 / 8 \mathrm{IC} \mathrm{C}_{50}\right)$.

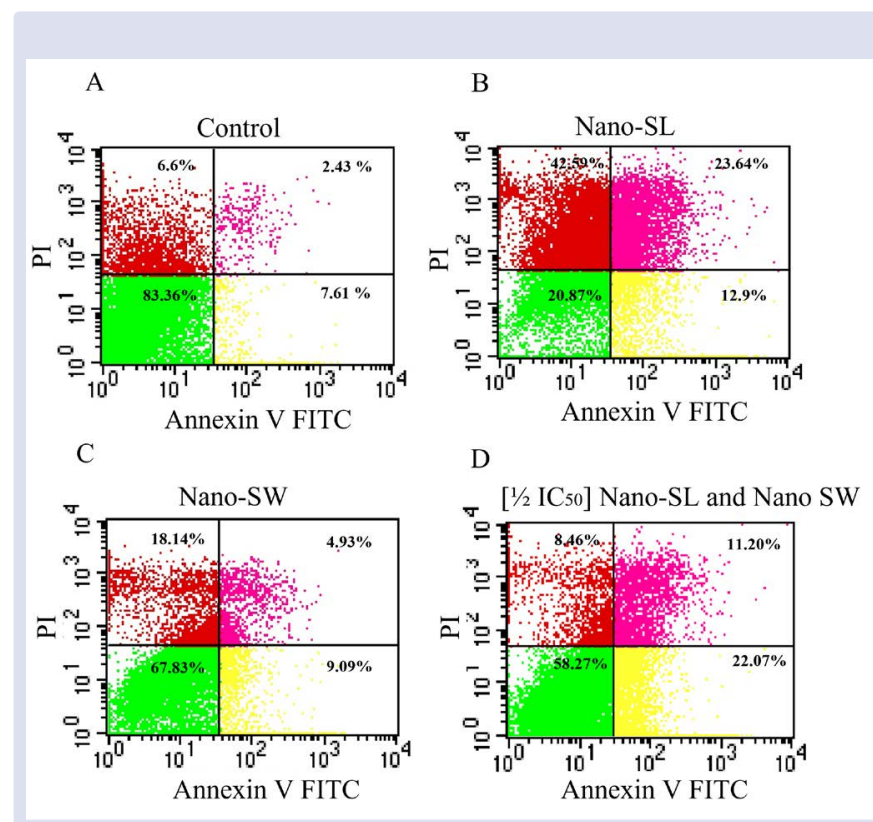

Figure 3: Distribution of apoptosis and necrosis-induced cell death in HeLa cells by single dose and combined dose of nanoparticles. A) control, B) Soursop leaves nanoparticle (nano-SL), C) Sappan wood nanoparticle (nano-SW). The treatment dose of $\mathrm{IC}_{50}$ is 63.32 $\mu \mathrm{g} / \mathrm{ml}$ (nano-SL) and $40.88 \mu \mathrm{g} / \mathrm{ml}$ (nano-SW). Counterclockwise from left-bottom showing live cell (green/low left), early apoptosis (yellow/low right), late apoptosis (pink/up right), necrosis (red/up left).

cells that can harm the body. ${ }^{41}$ Apoptosis is influenced by physiological processes that function to eliminate unwanted or useless cells during cell growth and other normal biological processes. ${ }^{41,42}$ On the other hand, necrosis is unregulated cell damage characterized by an increase in cell volume and loss of membrane pressure. Necrosis is caused by the release of lysosomal enzymes such as proteases and nuclease, leading the cells to undergo lysis followed by an inflammatory response. Necrosis is a pathological process due to exposure to physical or chemical stresses that are very influential on cells. ${ }^{42}$ Specific apoptosis-induced cancer cell death is thought to be the preferable therapeutic method to treat cancer. This is because necrosis promotes local inflammation which leads to extravasation and an increase in the diameter of the blood vessels close to the site to allow a greater amount of these lymphocytes to go to the site and control the infection/injury. The greater amount of blood that reaches the site of the tumor resulted in the more abundant nutrients provided for the cells that allow them to proliferate with renewed vigor.

A previous study ${ }^{43}$ has confirmed an efficient induction of apoptotic protein expression in lung carcinoma cancer cell line via silver nanoparticle of soursop aqueous leaf extract. The programmed cell death involved mitochondrial-mediated intrinsic pathways. ${ }^{44}$ Meanwhile, the purified compound of sappan wood (i.e., brazilin) induced apoptotic in skin cancer cells through caspase-3-dependent pathway. ${ }^{45}$ Based on our findings, both nanoparticles from soursop leaf and sappan wood were promising as an anticancer agent, either administered as a single-dose or combined-dose. Given the improved stability in the nanoparticle product has been achieved, the combined dose suggests a synergistic effect to produce a total effect that is greater than the sum of the individual agents. Since chitosan nanoparticles are widely studied as vehicles for drug delivery, it will be of future interest to optimize the method for synthesizing a stable nano-SL and nano-SW. 


\section{CONCLUSION}

Soursop leaf nanoparticle and sappan wood nanoparticle decreased the viability of HeLa cervical cancer cells with $\mathrm{IC}_{50}$ values of $63,32 \mu \mathrm{g} /$ $\mathrm{ml}$ dan $40,88 \mu \mathrm{g} / \mathrm{ml}$, respectively. The combined dose of $1 / 8 \mathrm{IC}_{50}$ from both nanoparticles showed a strong synergistic effect as shown by the combination index value of 0.13 based on the same mode of action and different modes of action. In HeLa cells treated with a combined dose of nanoparticles, the total apoptotic cells increased 1.5-2 times greater than that in control cells. The effectiveness of nanoparticle compounds to promote cell death is influenced by the stability of nanoparticle suspension.

\section{ACKNOWLEDGEMENT}

This research was supported by PNBP UNS research grant.

\section{CONFLICTS OF INTEREST}

The authors declare no conflict of interest.

\section{REFERENCES}

1. Lei $C$, Wang $Y$, Huang $Y$, et al. Up-regulated miR155 Reverses the Epithelial-mesenchymal Transition Induced by EGF and Increases Chemo-sensitivity to Cisplatin in Human Caski Cervical Cancer Cells. PLoS One. 2012;7(12):1-9. doi:10.1371/journal.pone.0052310

2. Rasjidi I. Epidemiologi Kanker Serviks. Indones J Cancer. 2009;III(3):103-108.

3. Yarbro $\mathrm{CH}$, Wujcik D, Gobel BH. Cancer Nursing: Principles and Practice. 8th Ed. Burlington: Jones \& Bartlett Learning; 2018.

4. Lander ES, Linton LM, Birren B, Nusbaum C, Zody MC, Baldwin J, et al. Initial sequencing and analysis of the human genome. Nature. 2001;409(6822):860-921. doi:10.1038/35057062

5. Kim E-C, Hwang Y-S, Lee H-J, Lee S-K, Park M-H, Jeon B-H, et al. Caesalpinia sappan Induces Cell Death by Increasing the Expression of p53 and p21WAF1/CIP1 in Head and Neck Cancer Cells. Am J Chin Med. 2005;33(3):405-414. doi:10.1142/S0192415X05003016

6. Zhang H, Sun X-F. Overexpression of Cyclooxygenase-2 Correlates with Advanced Stages of Colorectal Cancer. Am J Gastroenterol. 2002;97(4):1037-1041. doi:10.1111/j.1572-0241.2002.05625.x

7. Wang SL, Cai B, Cui CB, Zhang HF, Yao XS, Qu GX. Apoptosis induced by Caesalpinia sappan L. extract in leukemia cell line K562. Chin J Cancer. 2001;20(12):1376-1379.

8. Pawar CR, Landge AD, Surana SJ. Phytochemical and Pharmacological Aspects of Caesalpinia sappan. J Pharm Res. 2008;1(2):131-138.

9. Lim D-K, Choi U, Shin D-H. Antioxidative Activity of Some Solvent Extract from Caesalpinia sappan L. Korean J Food Sci Technol. 1996;28(1):77-82.

10. Baskar R, Rajeswari V, Kumar TS. In vitro antioxidant studies in leaves of Annona species. Indian J Exp Biol. 2007;45(5):480-485.

11. Taylor L. Technical data report for Graviola (Annona muricata). In: Herbal Secrets of the Rainforest. 2nd Ed. Sage Press; 2002:1-6.

12. Degli Esposti M, Ghelli A, Ratta M, Cortes D, Estornell E. Natural substances (acetogenins) from the family Annonaceae are powerful inhibitors of mitochondrial NADH dehydrogenase (Complex I). Biochem J. 1994;301(1):161-167. doi:10.1042/bj3010161

13. Zafra-Polo MC, González MC, Estornell E, Sahpaz S, Cortes D. Acetogenins from Annonaceae, Inhibitors of Mitochondrial Complex I. Phytochemistry. 1996;42(2):253-271. doi:10.1016/00319422(95)00836-5

14. Yuan S-SF, Chang H-L, Chen H-W, Yeh Y-T, Kao Y-H, Lin K-H, et al. Annonacin, a mono-tetrahydrofuran acetogenin, arrests cancer cells at the G1 phase and causes cytotoxicity in a Bax- and caspase3-related pathway. Life Sci. 2003;72(25):2853-2861. doi:10.1016/ s0024-3205(03)00190-5
15. Artanti AN, Astirin OP, Prayitno A. Cytotoxic Activity Of Non Polar Fraction From Annona Muricata L. Leaves On Hela And Raji Cell Line. J Pharm Sci Clin Res. 2016;1(2):112. doi:10.20961/jpscr. v1i2.1944

16. Suri SS, Fenniri H, Singh B. Nanotechnology-based drug delivery systems. J Occup Med Toxicol. 2007;2(1):1-6. doi:10.1186/17456673-2-16

17. Gelperina S, Kisich K, Iseman MD, Heifets L. The Potential Advantages of Nanoparticle Drug Delivery Systems in Chemotherapy of Tuberculosis. Am J Respir Crit Care Med. 2005;172(12):14871490. doi:10.1164/rccm.200504-613PP

18. Irianto HE, Muljanah I. Proses Dan Aplikasi Nanopartikel Kitosan Sebagai Penghantar Obat. Squalen. 2011;6(1):1-8. Available from: https://www.bbp4b.litbang.kkp.go.id/squalen-bulletin/index.php/ squalen/article/view/55/35

19. Fadholly A, Proboningrat A, Dewi Iskandar RP, Rantam FA, Sudjarwo SA. In vitro anticancer activity Annona squamosa extract nanoparticle on WiDr cells. J Ad Phar Tech \& Res. 2019;10(4):149154. DOI: 10.4103/japtr.japtr_10_19.

20. Jun SH, Cha S-H, Kim J-H, Yoon M, Cho S, Park Y. Silver Nanoparticles Synthesized Using Caesalpinia sappan Extract as Potential Novel Nanoantibiotics Against Methicillin-Resistant Staphylococcus aureus. J Nanosci Nanotechnol. 2015;15(8):55435552. doi:10.1166/jnn.2015.10204

21. Sasidharan S, Chen $Y$, Saravanan D, Sundram KM, Latha LY. Extraction, Isolation and Characterization of Bioactive Compounds From Plants' Extracts. African J Tradit Complement Altern Med. $2011 ; 8(1): 1-10$

22. Astirin OP, Artanti AN, Fitria MS, Perwitasari EA, Prayitno A Annonaa muricata Linn Leaf Induce Apoptosis in Cancer Cause Virus. J Cancer Ther. 2013;04(07):1244-1250. doi:10.4236/ jct.2013.47146

23. Rubiyanto D. Teknik Dasar Kromatografi. Deepublish; 2016.

24. Mardliyati E, Muttaqien S El, Setyawati DR. Sintesis Nanopartike Kitosan- Trypoly Phosphate Dengan Metode Gelasi Ionik: Pengaruh Konsentrasi dan Rasio Volume Terhadap Karakteristik Partikel. In: Prosiding Pertemuan IImiah IImu Pengetahuan Dan Teknologi Bahan. 2012:90-93. Available from: https://digilib.batan.go.id/ppin/ katalog/file/1411-2213-2012-1-090.pdf

25. Buxton R. Software Design Expert 7: Introduction, Mathematics Learning Support Centre. Published 2007 [cited 2018 Mar 27]. Available from: https://www.lboro.ac.uk/media/media/ schoolanddepartments/mlsc/downloads/Design-Expert-7.pdf

26. Danaei $M$, Dehghankhold $M$, Ataei $S$, Hasanzadeh Davarani $F$ Javanmard R, Dokhani A, Khorasani S, Mozafari MR. Impact of Particle Size and Polydispersity Index on the Clinical Applications of Lipidic Nanocarrier Systems. Pharmaceutics. 2018;10(2):57. doi: 10.3390/pharmaceutics10020057. PMID: 29783687; PMCID: PMC6027495

27. Patel S, Gheewala N, Suthar A, Shah A. In-vitro Cytotoxicity Activity of Solanum Nigrum Extract Against Hela Cell Line and Vero Cell Line. Int J Pharm Pharm Sci. 2009;1(SUPPL. 1):38-46.

28. Freshney RI. Culture of Animal Cells: A Manual of Basic Technique. Wiley-Liss; 2005

29. Walters J, Pop C, Scott FL, Drag M, Swartz P, Mattos C, et al. A constitutively active and uninhibitable caspase-3 zymogen efficiently induces apoptosis. Biochem J. 2009;424(3):335-345. doi:10.1042/BJ20090825

30. Stepanenko AA, Dmitrenko V V. Pitfalls of the MTT assay: Direct and off-target effects of inhibitors can result in over/underestimation of cell viability. Gene. 2015;574(2):193-203. doi:10.1016/j. gene.2015.08.009 
31. Hostanska K, Nisslein T, Freudenstein J, Reichling J, Saller R. Evaluation of Cell Death Caused by Triterpene Glycosides and Phenolic Substances from Cimicifuga racemosa Extract in Human MCF-7 Breast Cancer Cells. Biol Pharm Bull. 2004;27(12):19701975. doi:10.1248/bpb.27.1970

32. Cancer Chemoprevention Research Center. Preparasi Sampel untuk Siklus Sel dengan Metode Flow cytometry. 2014 [cited 2017 Oct 14]. Available from: https://ccrc.farmasi.ugm.ac.id/wp-content/ uploads/sites/1439/03.014.02-flowcytometry.pdf

33. Atale N, Gupta S, Yadav U. and Rani V. Cell-death assessment by fluorescent and nonfluorescent cytosolic and nuclear staining techniques. J Microscopy. 2014;255: 7-19. https://doi.org/10.1111/ jmi.12133

34. Cancer Chemoprevention Research Center. Protokol Uji in Vitro Cancer Chemoprevention Research Centre Farmasi UGM Published 2010 [cited 2017 Sept 26]. Available from: http://ccrc. farmasi.ugm.ac.id/?page_id $=240$

35. Reynolds CP, Maurer BJ. Evaluating Response to Antineoplastic Drug Combinations in Tissue Culture Models. Blumenthal RD, ed. Chemosensitivity. 2005;1: In Vitr(2):173-183. doi:10.1385/1-59259869-2:173

36. Arthur FKN, Woode E, Terlabi EO, Larbie C. Evaluation of acute and subchronic toxicity of Annona Muricata (Linn.) aqueous extract in animals. Eur J Exp Biol. 2011;1(4):115-124.

37. Nugroho YA, Soeradi DO. Toksisitas Akut dan Efek Pemberian Ekstrak Etanol Kayu Secang (Caesalpinia sappan L) terhadap Struktur Anatomi Tubulus Seminiferus Testis Tikus Putih. J Bahan Alam Indones. 2002;1(1):35-39.

38. Mohanraj VJ, Chen Y. Nanoparticles - A Review. Trop J Pharm Res. 2006;5(1):561-573. doi:10.4314/tjpr.v5i1.14634
39. Kamuhabwa A, Nshimo C, De Witte P. Cytotoxicity of some medicinal plant extracts used in Tanzanian traditional medicine. J Ethnopharmacol. 2000;70(2):143-149. doi:10.1016/S0378$8741(99) 00161-0$

40. Zhang G, Gurtu V, Kain SR, Yan G. Early Detection of Apoptosis Using a Fluorescent Conjugate of Annexin V. Biotechniques. 1997;23(3):525-531. https://www.biotechniques.com/multimedia/ archive/00011/97233pf01_11715a.pdf

41. Elmore S. Apoptosis: a review of programmed cell death. Toxicol Pathol. 2007;35(4):495-516. doi:10.1080/01926230701320337

42. Zappavigna S, Luce A, Vitale G, Merola N, Facchini S, Caraglia M. Autophagic cell death: A new frontier in cancer research. Adv in Biosci Biotech. 2013; 4: 250-262. doi: 10.4236/abb.2013.42034.

43. Meenakshisundaram $S$, Krishnamoorthy $V$, Jagadeesan $Y$, Vilwanathan R, Balaiah A. Annona muricata assisted biogenic synthesis of silver nanoparticles regulates cell cycle arrest in NSCLC cell lines. Bioorg Chem. 2020;95:103451. doi:10.1016/j. bioorg.2019.103451

44. Moghadamtousi SZ, Kadir HA, Paydar M, Rouhollahi E, Karimian H. Annona muricata leaves induced apoptosis in A549 cells through mitochondrial-mediated pathway and involvement of NF-KB. BMC Complement Altern Med. 2014;14(1):1-13. doi:10.1186/1472-688214-299

45. Liang $\mathrm{CH}$, Chan LP, Chou TH, Chiang FY, Yen CM, Chen PJ, Ding HY, Lin RJ. Brazilein from Caesalpinia sappan L. Antioxidant Inhibits Adipocyte Differentiation and Induces Apoptosis through Caspase-3 Activity and Anthelmintic Activities against Hymenolepis nana and Anisakis simplex. Evid Based Complement Alternat Med. 2013;864892. doi: 10.1155/2013/864892. 


\section{GRAPHICAL ABSTRACT}

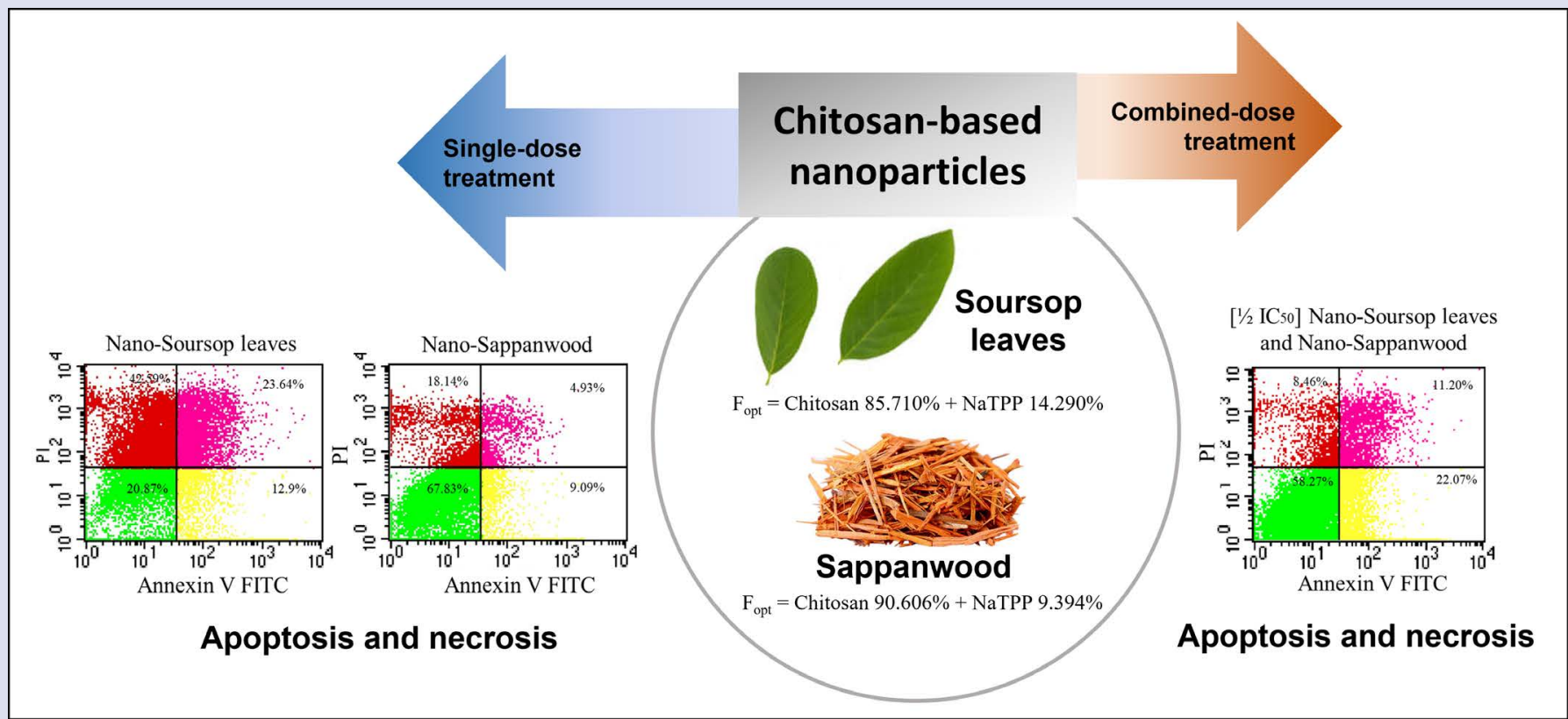

\section{ABOUT AUTHORS}

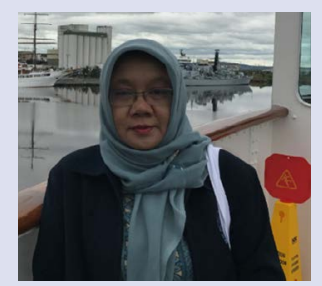

Okid Parama Astirin received her master degree at Gadjah Mada University and doctoral degree at Brawijaya University before she became a full professor at Sebelas Maret University. Her research focuses on the development of nanomaterials from natural product targeting cancer cells, whereby she has received numerous national research grants and conducted partnership with many institutions. She has published research articles in the reputable journals in the area of her studies. She is also actively engaged in the community services and granted intellectual property rights in the application of biogas from tofu liquid waste.

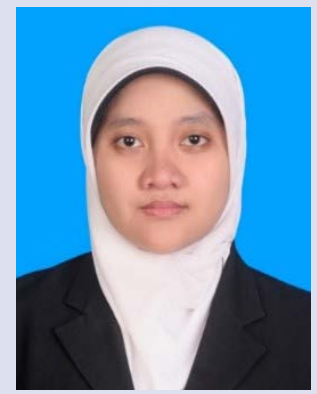

Anif Nur Artanti received her undergraduate and master degree from one of the most prestigious universities in Indonesia, Gadjah Mada University, Faculty of Pharmacy. She is currently a lecturer in the Department of Pharmacy, Vocational College, Sebelas Maret University, Sebelas Maret University. Her research specialties are pharmaceutical biology, pharmacognosy, phytochemistry, and phytopharmaceuticals. She actively publishes articles in various scientific journals, e.g., International Journal Pharmaceutical Sciences Asia, as well as becoming an invited speaker particularly on the topic of natural product. In 2018, she attended training on flowcytometry at the National University of Singapore.

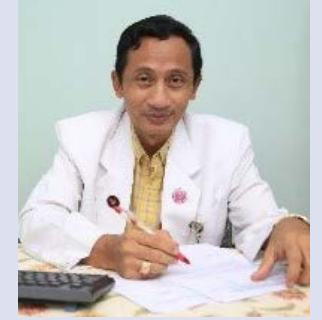

Professor Adi Prayitno, drg, MKes, SpPMM(K) is well-known scientist in the field of oral and maxillofacial pathobiology and pathology. He graduated from Tropical Disease Study Program, Gadjah Mada University (master program) in 1997, then continued his doctoral program in the Faculty of Medicine, Airlangga University. Besides devoting his main time for his profession as a medical doctor, he also teaches graduate school students in molecular biology, immunology, and pathobiology in Sebelas Maret University. 


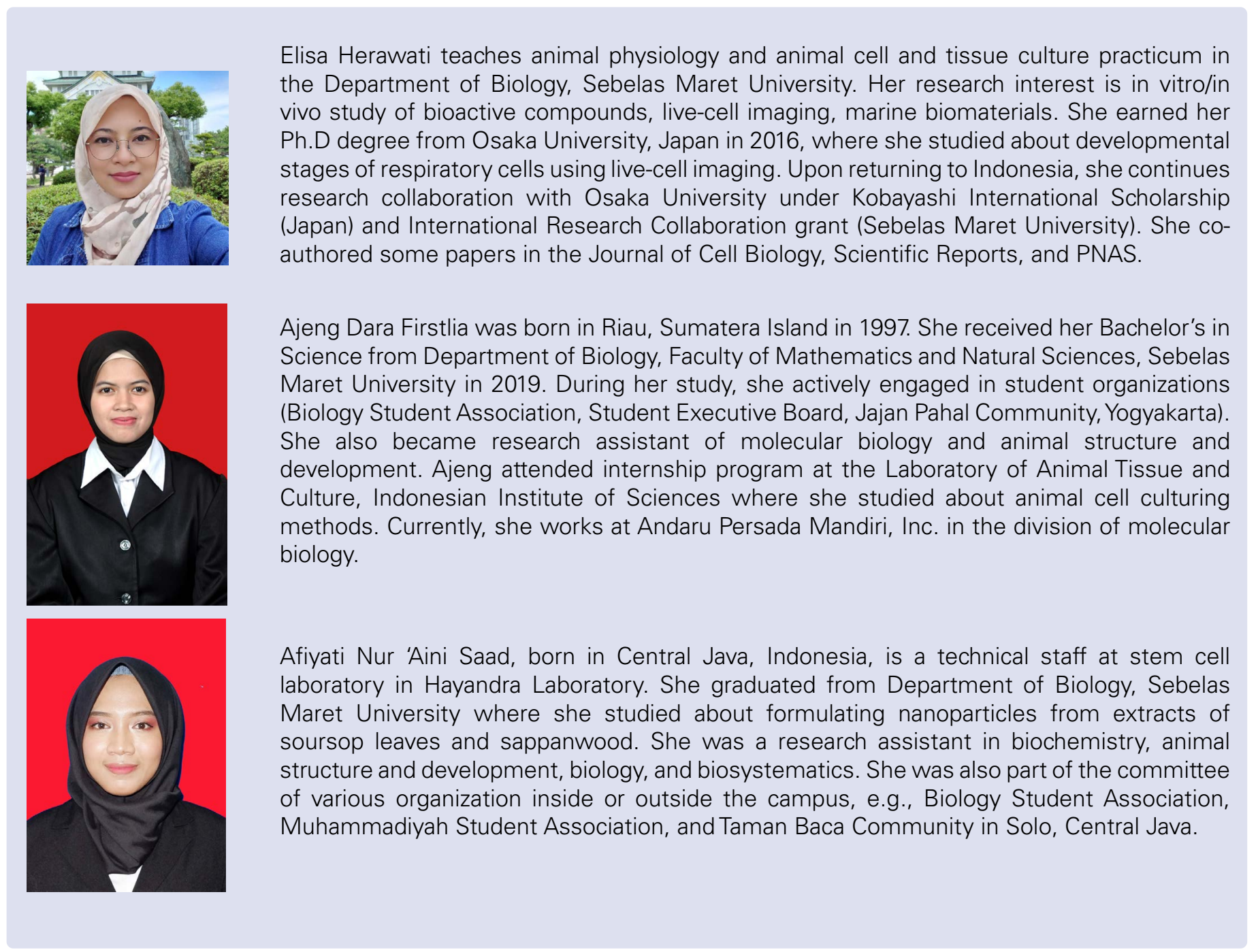

Cite this article: Astirin OP, Prayitno A, Artanti AN, Herawati E, Saad ANA, Firstlia AD. Single-Dose and Combined-Dose of Nanoparticles from Soursop Leaves (Annona muricata L.) and Sappan Wood (Caesalpinia sappan L.) Induced Apoptosis and Necrosis in HeLA Cells. Pharmacogn J. 2021;13(5): 1134-1142. 